\title{
脂質代謝における Lipin1
}

\author{
石 本 憲 司
}

\section{Lipin 1 in Lipid Metabolism}

\author{
Kenji IsHimoto \\ Graduate School of Pharmaceutical Sciences, Osaka University, 1-6 Yamadaoka, \\ Suita, Osaka 565-0871, Japan
}

(Received March 30, 2011)

\begin{abstract}
The gene encoding lipin 1 was identified with a positional cloning approach that localized the causative mutation in fatty liver dystrophic $(f d)$ mice, a mouse model of lipodystrophy. The $f l d$ mouse lacks normal adipose tissue in the body, and displays metabolic dysregulation such as obesity, insulin resistance, and hypertriglyceridemia. Lipin 1 is abundantly expressed in key metabolic tissues, including adipose tissue, skeletal muscle, and liver. In the cytosol, lipin 1 acts as an $\mathrm{Mg}^{2+}$-dependent phosphatidate phosphatase type-1 (PAP1), catalyzing a key step in the synthesis of glycerolipids. In the nucleus, lipin 1 acts as a transcriptional coactivator through its direct interaction with peroxisome proliferator-activated receptor (PPAR) $\gamma$ coactivator- $1 \alpha$ (PGC- $1 \alpha$ ) and PPAR $\alpha$. Through two distinct functions in the nucleus and cytosol, lipin 1 modulates lipid metabolism and glucose homeostasis. Here we will discuss recent developments in our understanding of the role of lipin 1 in lipid metabolism.
\end{abstract}

Key words - lipin 1; lipid metabolism; sterol regulatory element-binding protein; gene regulation; phosphatidate phosphatase; promoter

\section{1. はじめに}

近年の多くの研究から，エネルギー代謝や脂肪蓄 積に係わる脂肪組織が, 代謝の恒常性維持にとって 中心的な役割を担っていることが知られている．特 に生体内の脂肪組織量のバランスは重要な要因と考 えられ，その量が多すぎても少なすぎても脂質代謝 異常が発生し，糖尿病やインスリン抵抗性，高トリ グリセリド血症などの病態を呈する. 1,2) すなわち, 脂肪蓄積量増大に伴う肥満が影響する症状と，その 肥満と対照的な位置づけにある全身性脂肪萎縮症 （全身の脂肪組織が欠落した疾患）で起こる症状は 同一である。これら 2 つ病態に共通する問題点 は, 脂肪組織の機能異常, 特に種々のアディポカイ ンを分泌する内分泌細胞としての機能不全であ る. ${ }^{3)}$ 例えば代表的なアディポカインであるレプチ ンは，視床下部での摂食抑制作用，末梢組織での脂

大阪大学大学院薬学研究科生命情報解析学分野 (T565 -0871 大阪府吹田市山田丘 1-6)

e-mail: kenji@phs.osaka-u.ac.jp

本総説は, 平成 22 年度日本薬学会近畿支部奨励賞（生 物系薬学) の受賞を記念して記述したものである.
肪酸合成抑制作用や脂肪酸酸化促進作用が知られて おり，脂質の恒常性を維持するために必要である.

一方，肥満によるレプチンの過剰分泌は，その感受 性が低下しインスリン抵抗性を引き起こす。このよ うに，肥満にも脂肪萎縮症にもならないような一定 量の脂肪組織量を維持することがヒトの健康に必須 である。そこで本稿では，脂質の恒常性維持の鍵因 子 Lipin1 タンパク質に着目し，筆者らが今日まで 得た研究成果を主に紹介するとともに, 脂質代謝に おけるLipin1 タンパク質の構造と機能について概 説する.

\section{Lipin1 遺伝子と代謝調節}

Lipin1 遺伝子は, 脂肪萎縮症のモデルマウスで ある fatty liver dystrophy（ $f d d)$ マウスの原因遺伝 子として 2001 年に発見された. ${ }^{4)}$ fld マウスでは, 内臓や皮下の白色脂肪細胞や肩甲骨間の褐色脂肪細

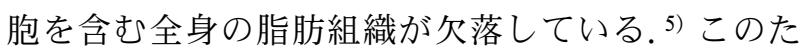
め，脂質が肝臓，骨格筋，血管内などの非脂肪組織 に移り，インスリン抵抗性， 2 型糖尿病，高トリグ リセリド血症, 脂肪肝のような代謝異常を呈する. またこのマウスでは，ヒトの脂肪萎縮症患者の一部 
でしか観察されない末梢神経障害を示す.

Lipin1 遺伝子を過剩に発現させたトランスジェ ニックマウスでは，肥満を促進させる. ${ }^{6)}$ Adipocyte fatty acid binding protein 由来のプロモーターを用 いて脂肪組織特異的に発現する Lipin1 トランスジ エニックマウスを解析すると，正常マウスと比較し て脂肪細胞数に変化はないが，Fatty acid synthase や Acetyl-CoA carboxylase, Diacylglycerol acyltransferase を含む脂質生合成遺伝子の発現が上昇し, 脂肪細胞中のトリグリセリド量が増加する。 ${ }^{7)}$ また, Muscle creatine kinase 由来プロモーターを用いて 作製した筋肉特異的な Lipin1 トランスジェニック マウスでも，脂肪酸酸化によるエネルギー消費の減 少やトリグリセリド増加による肥満が観察される. このように，脂肪あるいは筋肉特異的に Lipin1 を 発現させたマウスの両方において肥満が生じるが, 興味深い相違点がある．筋特異的な Lipin1 トラン スジェニックマウスでは，脂質蓄積によるインスリ ン抵抗性が予想通り観察される。一方，脂肪特異的 なトランスジェニックマウスでは，肥満状態である にもかかわらず，血中グルコースやインスリンレベ ルが正常マウスより減少し，インスリン感受性が改 善されている。このメカニズムは不明であるが，脂 肪組織でより効果的に脂肪酸を取り込むことによ り，骨格筋や膵藏のような組織での脂肪蓄積が減少 し，全身のインスリン感受性が改善された可能性が ある。

\section{Lipin1 の構造と機能}

Lipin1 タンパク質は，構造的に類似した特徵を 持つ Lipin2, Lipin3 とともに Lipin ファミリーに属 する（Fig. 1)。Lipin1 は，肝臓や脂肪組織，骨格 筋などの脂質代謝が盛んな臓器で発現する. ${ }^{4,8)}$ 一方 Lipin2 は肝臟や脳で多く発現し，Lipin3 は小腸や 肝臟などの組織で少ないながら発現している. ${ }^{91}$ な お Lipin1では，マウスにおいて選択的スプライシ ングによる 2 種類のアイソフォーム, Lipin $1 \alpha$ と Lipin1 $\beta$ が同定されている. ${ }^{7)}$ 一方ヒトでは, $\operatorname{Lipin} 1 \alpha, \operatorname{Lipin} 1 \beta$ のほかに，ヒト胎児脳 $\mathrm{cDNA}$ か らクローンニングされた Lipin $1 \gamma$ の存在が報告され ている. ${ }^{10)}$

Lipin ファミリーは，非哺乳類を含む広範な種で 保存されている. ${ }^{11,12)}$ すべての Lipin タンパク質に は，核移行シグナルである Nuclear localization sig-

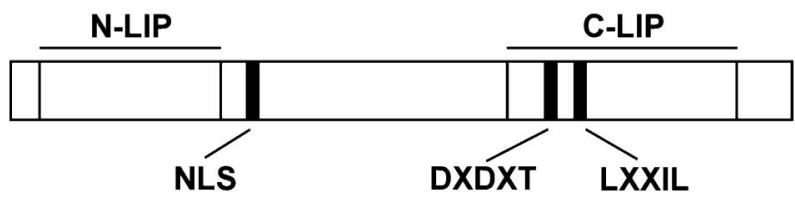

Fig. 1. Lipin Protein Domains and Functional Motifs

nal（NLS）やいくつかのセリン/スレオニンでリン 酸化を受けるサイトが存在する。ささらに，Lipin 夕 ンパク質の $\mathrm{N}$ 末端側と $\mathrm{C}$ 末端側には，高い相同性 を持つ領域 N-LIP ドメインと C-LIP ドメインが存 在し，これらのドメインが Lipinの重要な機能を担 うことが考えられる。実際に C-LIP ドメインには, Lipin1 の生理的機能に寄与する DXDXT（X は任 意のアミノ酸）触媒ドメインと LXXIL モチーフを 含んでいる.

Lipin1 タンパク質は, 細胞内局在の違いによる 2 つの脂質代謝調節機能が知られている (Fig. 2)。1 つ目として Lipin1 は，トリグリセリドやリン脂質 の生合成経路を促進するホスファチジン酸ホスファ ターゼ (Phosphatidate phosphatase; PAP) 活性を 持つ. ${ }^{9,13)}$ PAP は植物を含む幅広い種間で存在し, 小胞体膜上においてホスファチジン酸を脱リン酸化 することでジアシルグリセロールを生成する。また PAPには, $\mathrm{Mg}^{2+}$ に依存的な PAP1 活性と $\mathrm{Mg}^{2+}$ に非依存的な PAP2 活性があり，Lipin1 はPAP1 活性を有することが知られている。この PAP1 活 性は，Lipin1 タンパク質の C-LIP ドメイン内に存 在している DXDXT 触媒ドメインが寄与する.

次に Lipin1 は，転写共役因子として核内で機能 する. ${ }^{14,15)}$ Lipin1 タンパク質の C-LIP ドメインにあ る LXXIL モチーフを介して，核内受容体 Peroxisome proliferator-activated receptor $\alpha(\operatorname{PPAR} \alpha)$ や 他の転写共役因子 PPAR $\gamma$ coactivator- $1 \alpha(\mathrm{PGC} 1 \alpha)$ と結合し, 脂肪酸酸化に関連する $\mathrm{PPAR} \alpha / \mathrm{PGC} 1 \alpha$ の標的遺伝子 (Acyl CoA oxidase, PPAR $\alpha$, Carnitine palmitoyl transferase-1）の発現を制御する。ま

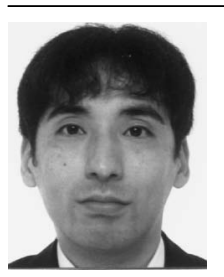

石本憲司
大阪大学大学院薬学研究科生命情報解 析学分野・助教 博士 (薬学). 山口県 出身. 2001 年東京薬科大学薬学部卒業, 2003 年北海道大学大学院薬学研究科修 士課程修了, 2006 年大阪大学大学院薬 学研究科博士課程修了. 2006 年大阪大 学医学部特任研究員を経て, 2009 年 10 月より現職。 


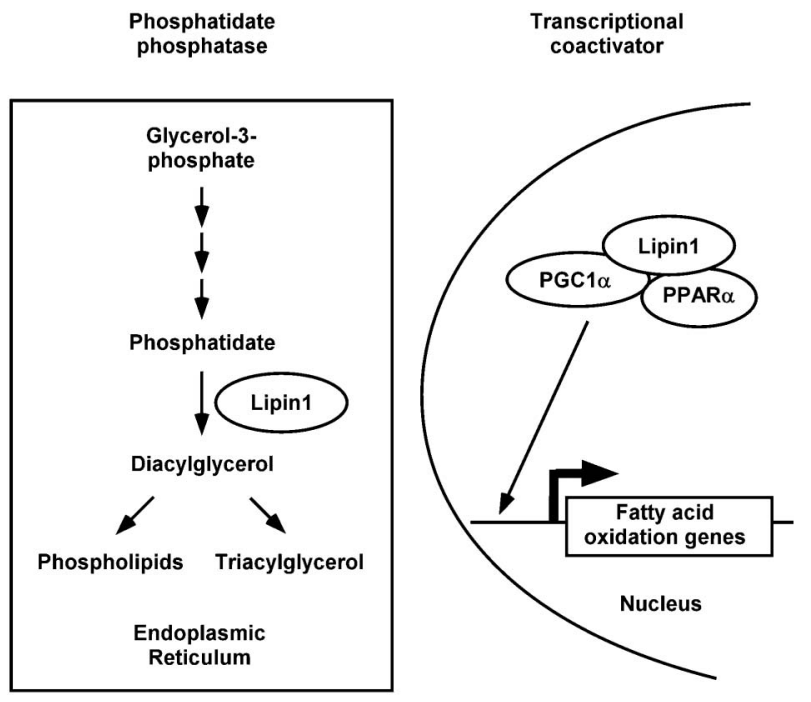

Fig. 2. Dual Molecular Functions of Lipin 1 Protein as Phosphatidate Phosphatase and Transcriptional Coactivator

た Lipin1 は，核内受容体 Hepatocyte nuclear factor $4 \alpha$ やPPAR $\delta$, PPAR $\gamma$, Glucocorticoid receptor とも 相互作用することが知られている. 以上のことから Lipin1 は，エネルギーを細胞内に貯蓄する前者の 機能と細胞内エネルギーを消費する後者の機能を持 つ二面性のタンパク質である。したがって，Lipin1 が脂質調節を行うための複雑なシステムを理解する ためには，多面的な解析が必要であると考えられる.

4. 細胞内ステロールによるLipin1 遺伝子発現 への影響

前述したように，Lipin1 は生体内の脂質代謝に 深く関連している因子である。しかし，Lipin1 遺 伝子の発現がどのような機構で制御されているかほ とんごわかっていない。この発現制御機構が解明で きれば，Lipin1による脂質調節を理解するための 新たな知見が得られると考えられる。 そこで, 細胞 膜や生理活性物質などの材料となる脂質成分である ステロール（コレステロールやヒドロキシコレステ ロールなど）に着目し，細胞内ステロールと Lipin1 遺伝子発現の関係を調べた. ${ }^{16)}$

まず細胞内のステロール量を厳密に調節するため に，脂質を除去した FBS である Lipoprotein-deficient serum（LPDS）を用いて 3 種類の条件を設定 した. すなわち，LPDS(培地中に脂質がない状態)，

Sterols（LPDS 条件にコレステロールと25-ヒドロ キシコレステロールを加えた培地)，Statin（LPDS 条件にコレステロール生合成経路を遮断する

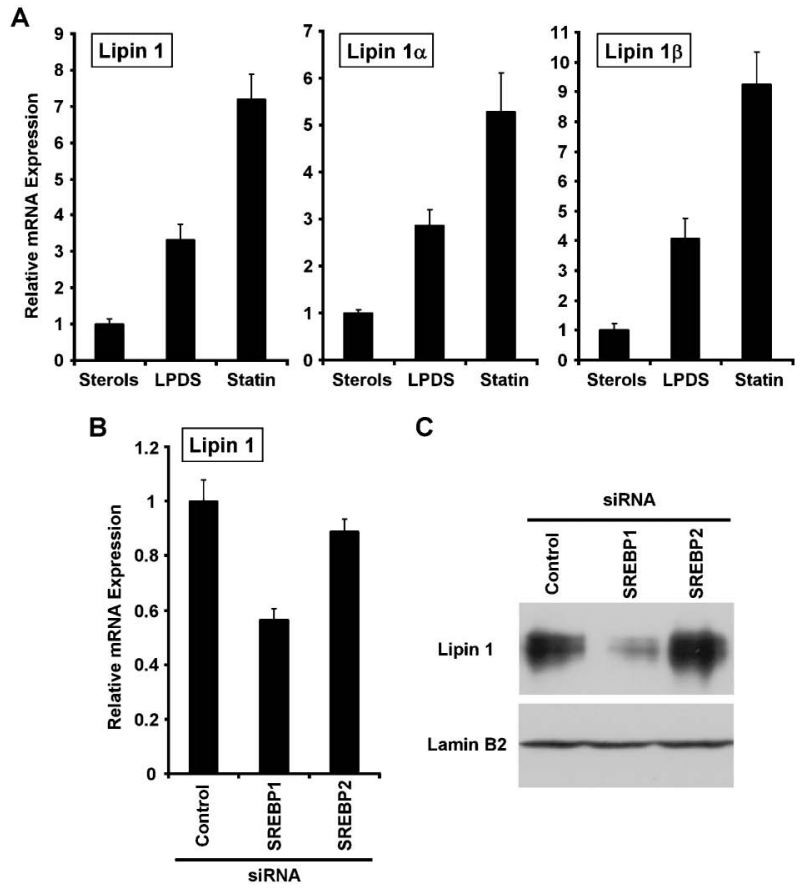

Fig. 3. Lipin 1 Expression Regulated by Cellular Sterols in Huh7 Cells

(A) Huh7 cells were cultured for $24 \mathrm{~h}$ in medium containing sterols, LPDS, or statin. Lipin 1 , lipin $1 \alpha$, and lipin $1 \beta$ mRNA levels were normalized to those of $36 \mathrm{~B} 4 \mathrm{mRNA}$. All values are expressed as means \pm S.E.M. ( $n$ $=3$ ). (B, C) Knockdown of SREBP-1 reduces lipin 1 expression in Huh-7 cells. Huh7 cells were transfected with $25 \mathrm{nM}$ control, SREBP-1, or SREBP2 siRNA. (B) Total RNA was extracted for analysis by real-time RT-PCR 24 $\mathrm{h}$ after transfection. Target mRNA levels were normalized to cyclophilin A mRNA levels. All values are expressed as means \pm S.E.M. $(n=3)$. (C) Forty-eight hours after transfection, cell extracts were prepared, and aliquots were subjected to SDS-PAGE. Immunoblots were probed with anti-lipin 1 antibody or anti-lamin B2 antibody.

HMG-CoA 還元酵素阻害剂であるスタチンを加え た培地）の条件である。この設定した条件における 細胞内ステロール量は, Sterols, LPDS, Statin の順 番で多くなる。これらの培地条件を用いて，ヒト肝 がん由来 Huh7 細胞における Lipin1 mRNA 量の変 化をリアルタイム PCR 法を用いて調べた [Fig. 3 (A) ]。その結果，細胞内ステロール量が減少する につれて, Lipin1 mRNA 量は増加していた。また, Lipin1 のアイソフォームである $\operatorname{Lipin} 1 \alpha, \operatorname{Lipin} 1 \beta$ についても同様な結果が得られた。これらのことか ら Lipin1 の発現は，アイソフォームに関係なく, 細胞内ステロール量が変化することで制御されるこ とが明らかとなった。

細胞内ステロールが枯渴すると活性化する転写因 子として Sterol regulatory element-binding protein (SREBP) が知られている. ${ }^{17-19)}$ SREBP は, SREBP1 と SREBP-2 の 2 つのアイソフォームが存在し, 
SREBP-1 は主に脂肪酸やトリグリセリドを生合成 する遺伝子を，SREBP-2 は主にコレステロールを 生合成する遺伝子を制御している。筆者たちは, SREBP タンパク質が Lipin1 の発現を調節している のではないかと考え，SREBP-1 と SREBP-2 の siRNA を用いて検討した [Fig. 3 (B) and (C)]. LPDS 条件下の Huh7 細胞において, SREBP-2 siRNA を用いた時の Lipin1 発現量は，コントロー ルと比較して変化がなかった。一方 SREBP-1 siR$\mathrm{NA}$ を用いた時では，コントロールと比較して有意 にLipin1 発現量が減少していた。したがって, Lipin1 遺伝子は，転写因子 SREBP-1 によって制御 されていた.

\section{SREBP-1 による Lipin1 遺伝子の転写制御機} 構

次に細胞内ステロールによるLipin1 遺伝子の発 現制御メカニズムをより詳細に解析するために，転 写開始点から約 $2.6 \mathrm{~kb}$ (野生型) のヒト Lipin1 プ ロモーターを組み込んだレポータープラスミドを構 築した。また，野生型 Lipin1 プロモーターを順次 欠失させた様々なコンストラクトも作製し，ヒト肝 がん由来 HepG2 細胞にこれらすべてのレポーター プラスミドを導入し，ルシフェラーゼアッセイを行 つた [Fig. 4(A) ]。その結果，野生型の Lipin1 プ ロモーターにおいて，細胞内ステロールが減少する につれて，転写活性化が増大した。この応答性は一 2478 の長さまでは観察されたが，-2378 の長さま で欠失させると，ステロール枯渇による応答性が著 しく減少した。このことから，ヒト Lipin1 プロ モーターのー2478 から-2378 の間に細胞内ステ ロールに応答する領域が存在すると予測された。 そ こで，この領域の配列を解析したところ，SREBP1 が制御する配列である SRE モチーフが存在した [Fig. 4(B)]。また，SREBP が最大の転写活性化を 得るために必要な配列 Nuclear factor Y (NF-Y) 結合サイトも発見した. ${ }^{20,21)}$ このサイトには転写因 子 NF-Y が結合することが知られている. ${ }^{22)}$

そこで, Lipin1 プロモーター中のこれら $2 つ 0$ 領域が SREBP-1 によって調節されているか調心゙ た。具体的には SRE モチーフと NF-Y 結合サイト のそれぞれ，あるいは両方に変異を入れたレポー タープラスミドを作製し，これらのプラスミドに対 する SREBP-1 の応答性を調べた [Fig. 4(C)]。そ
A

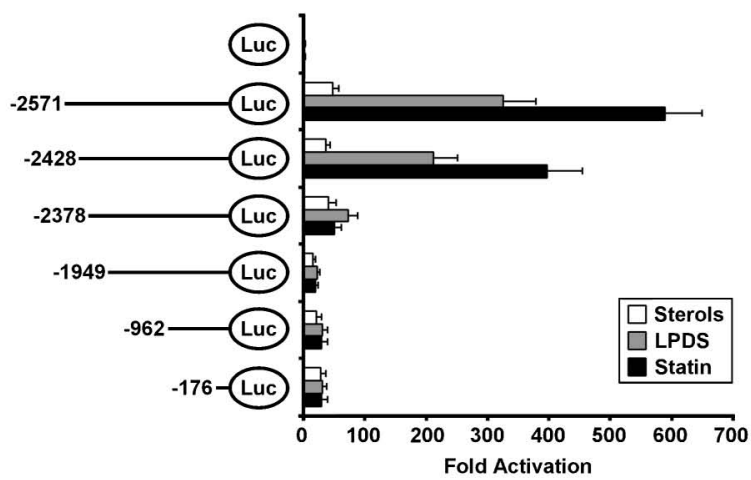

B SRE

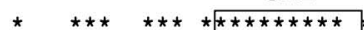
Human -2428 CTGGAGTTCCTTCTCCTCTTCCGAGTGC Mouse -1936 ATTAGGTTATTTCCDCTCTTCCGACTTG Consensus NNCNNNCNAN
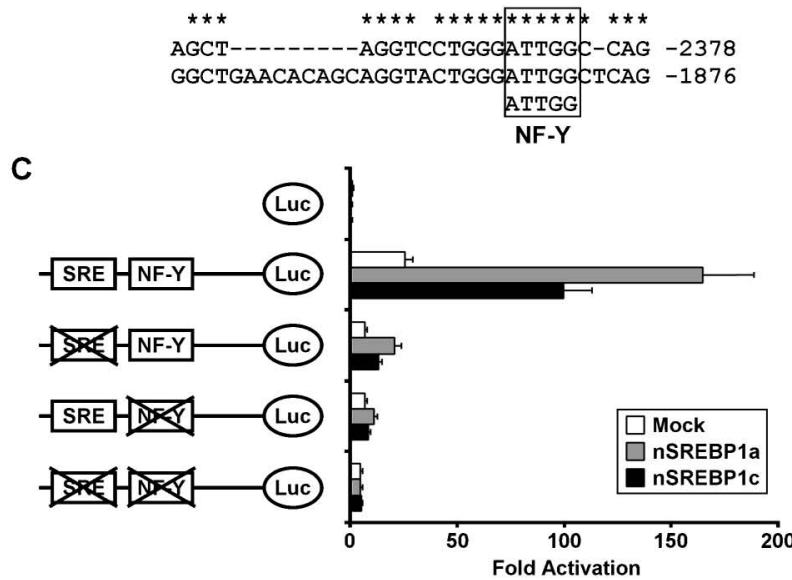

Fig. 4. The Region between Nucleotides -2428 and -2378 of the Human Lipin 1 Promoter Contains Sequences that Mediate the Induction of Lipin 1 Expression by Sterol Depletion

(A) HepG2 cells were transiently transfected with luciferase reporter constructs of the lipin 1 promoter. The cells were harvested and the luciferase activity was measured and normalized to the $\beta$-galactosidase activity. The values represent means \pm S.E.M. $(n=3)$. (B) Schematic representation of the human lipin 1 gene between nucleotides -2428 and -2378 , illustrating the SRE motif and the NF-Y-binding site. Conserved nucleotides are indicated by asterisks. (C) Reporter constructs were cotransfected into HepG2 cells with pcDNA3 (mock), SREBP-1a (nSREBP1a), or SREBP-1c (nSREBP1c) expression vector. The cells were harvested, and the luciferase activity was measured and normalized to the $\beta$-galactosidase activity. The values represent means \pm S.E.M. $(n=3)$.

の結果，野生型プロモーターでは SREBP-1 により 強い転写活性を示した。一方，作製したすべての変 異体において，SREBP-1 による転写活性化が大き く減少した。これらのことより, Lipin1 遺伝子の 発現制御は，細胞内ステロールの枯渇により活性化 した SREBP-1 が Lipin1 プロモーターに結合し，転 写を調節していることが明らかとなった。 
6. 細胞内ステロールに制御される Lipin1 はト リグリセリド合成を制御する

Lipin1 は 2 つの脂質調節機能として,「トリグリ セリド生合成酵素過程における PAP1 活性」と 「転写共役因子として脂肪酸酸化促進」を持つ. ${ }^{11,12}$ そこで，細胞内ステロールにより制御される Lipin1 が，これら 2 つ機能のどちらに関与する か検討した。まず細胞内ステロール量を変化させた Huh7 細胞を回収・分画し，Lipin1 の細胞内局在を 調べた [Fig. 5(A)]。その結果，PAP 活性として 機能する場である膜成分や細胞質成分において, Lipin1 タンパク質の発現増加が確認できた。一方, Lipin1 が転写共役因子として機能する場である核 成分では，Lipin1 タンパク質の増減は観察されな かった。これらの結果から，細胞内ステロールの枯 渴により発現が誘導される Lipin1 は，PAP1 活性 を有していると予測されたため，実際にPAP 活性

A
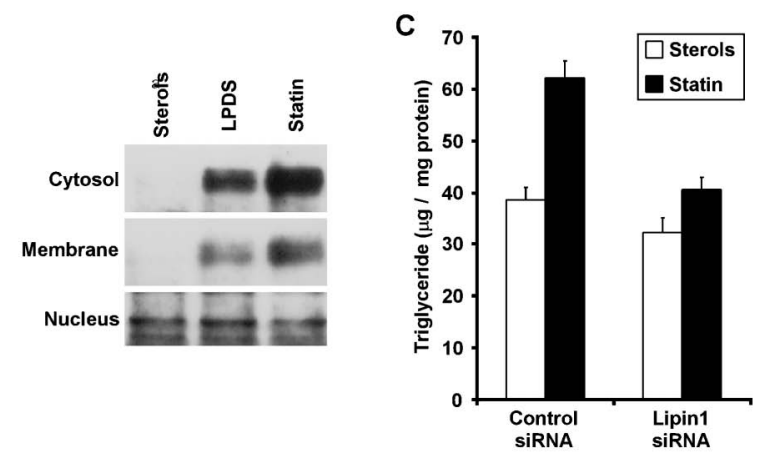

B
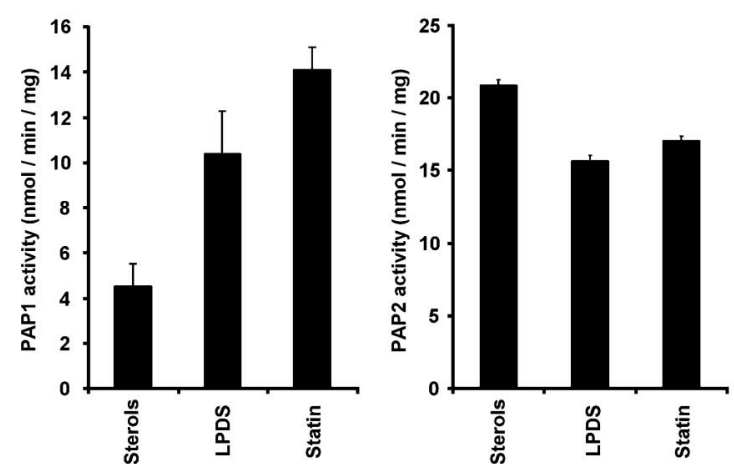

Fig. 5. Sterol-mediated Lipin 1 Expression Modulates Triglyceride Accumulation through Its PAP1 Activity in Huh7 Cells

(A) Huh7 cells were cultured in medium containing sterols, LPDS, or statin for $24 \mathrm{~h}$. Cell extracts were fractionated, and aliquots were subjected to SDS-PAGE. Immunoblots were probed with anti-lipin 1 antibody. (B) Huh7 cells were cultured in medium containing sterols, LPDS, or statin for $48 \mathrm{~h}$. PAP activity was measured using the cytosolic fraction. The values represent means \pm S.E.M. $(n=3)$. (C) Huh7 cells were transfected with each siRNA and cultured in medium containing sterols or statin for $72 \mathrm{~h}$. The cellular TG content was measured and normalized to the total protein content. The values represent means \pm S.E.M. $(n=3)$.
を測定した [Fig. 5(B)]。その結果，Lipin1の発現 増加と相関するように PAP1 活性が上昇したが, PAP2 活性にはほとんど影響を与えなかった。最後 に，Lipin1 に対する siRNA を用い，最終生成物で ある細胞内トリグリセリド量を調べた［Fig. 5 (C) ]. コントロール siRNA を導入した場合では, 細胞内ステロールを枯渇させることによりトリグリ セリド量は増加した。しかしながら，Lipin1 siRNA ではトリグリセリド量の変化が観察されなかっ た．以上のことから，細胞内ステロールにより制御 されるLipin1 は，PAP1 活性を通じて，細胞内卜 リグリセリドを調節していると考えられた。

\section{7. おわりに}

メタボリックシンドロームは，高血糖，脂質代謝 異常，高血圧が重積する病態であり，動脈硬化の前 駆状態として注目されている。このメタボリックシ ンドロームの予防策として，上流の原因である内臓 肥満を解消することが重要となる。このような背景 の中，2001 年に発見された Lipin1 遺伝子は，年月 を重ねる毎に注目度を増し，興味深い報告がいくつ もなされている。特に Lipin1 遺伝子発現制御の破 綻は，生体内の脂質バランスを崩し，肥満やインス リン抵抗性などの代謝異常が生じる。したがって, Lipin1 発現を厳密に制御できれば，これらの脂質 異常に対する有効な対策や治療法が開発できると考 えられる。一方，Lipin1 は「トリグリセリド合成」 と「脂肪酸酸化」という対局した 2 つの機能を有し ており，生体内においてこれらの機能を使い分ける 制御システムが存在すると予想されるがいまだに明 らかとされていない，その一端として，筆者たちの 結果である SREBP-1 が Lipin1 を制御するという事 象から，SREBP-1の上流シグナルであるインスリ ンが 1 つの要因であると予測する。すなわち，食事 を摄取した時に過剩の糖や脂質を血中から取り除く ためにインスリンが分泌され，SREBP-1 を活性化 し，Lipin1 発現による「トリグリセリド合成」を 促進すると考えられる。しかしがら，SREBP-1 は「脂肪酸酸化」が機能する場面では発現が抑制さ れているため，Lipin1 が「脂肪酸酸化」を調節す る新しい制御システムが存在する可能性がある、今 後, 脂質調節機能における Lipin1 の正確なメカニ ズムを詳細に理解し，メタボリックシンドロームを 始めとする脂質代謝異常に対する新しい治療戦略を 
提唱していきたい.

謝辞本研究は, 大阪大学大学院薬学研究科生 命情報解析学分野で行われた研究であり，終始，御 指導，御鞭撻を賜りました土井健史教授に心から感 謝申し上げます。また，本研究を行うに当たり，御 協力と御助言を賜りました橘 敬祐助教を始めとす る同研究室の皆様に心より御礼申し上げます。本研 究を推進するに当たり, 幾多の御協力と有益な御助 言を賜りました東京大学先端科学研究センターシス テム生物医学ラボラトリー児玉龍彦教授，酒井寿郎 教授, 浜窪隆雄教授, 田中十志也准教授, 大阪大学 大学院医学系研究科平野賢一助教, 大田明生博士に 深謝致します。

\section{REFERENCES}

1) Reue K., Phan J., Curr. Opin. Clin. Nutr. Metab. Care, 9, 436-441 (2006).

2) Garg A., N. Engl. J. Med., 350, 1220-1234 (2004).

3) Ahima R. S., Obesity, 14, 242-249 (2006).

4) Peterfy M., Phan J., Xu P., Reue K., Nat. Genet., 27, 121-124 (2001).

5) Reue K., Xu P., Wang X. P., Slavin B. G., $J$. Lipid Res., 41, 1067-1076 (2000).

6) Phan J., Reue K., Cell Metab., 1, 73-83 (2005).

7) Peterfy M., Phan J., Reue K., J. Biol. Chem., 280, 32883-32889 (2005).

8) Huffman T. A., Mothe-Satney I., Lawrence J. C., Proc. Natl. Acad. Sci. USA, 99, 10471052 (2002).

9) Donkor J., Sariahmetoglu M., Dewald J.,
Brindley D. N., Reue K., J. Biol. Chem., 282 , 3450-3457 (2007).

10) Han G. S., Carman G. M., J. Biol. Chem., 285, 14628-14638 (2010).

11) Reue K., Zhang P. X., FEBS Lett., 582, 90-96 (2008).

12) Khalil M. B., Blais A., Figeys D., Yao Z. M., Biochim. Biophys. Acta, 1801, 1249-1259 (2010).

13) Han G. S., Wu W. I., Carman G. M., J. Biol. Chem., 281, 9210-9218 (2006).

14) Finck B. N., Gropler M. C., Chen Z. J., Leone T. C., Croce M. A., Harris T. E., Lawrence J. C., Kelly D. P., Cell Metab., 4, 199-210 (2006).

15) Santos-Rosa H., Leung J., Grimsey N., PeakChew S., Siniossoglou, S., EMBO J., 24, 1931 -1941 (2005).

16) Ishimoto K., Nakamura H., Tachibana K., Yamasaki D., Ota A., Hirano K., Tanaka T., Hamakubo T., Sakai J., Kodama T., Doi T., J. Biol. Chem., 284, 22195-22205 (2009) .

17) Brown M. S., Goldstein J. L., Cell, 89, 331340 (1997).

18) Brown M. S., Goldstein J. L., Proc. Natl. Acad. Sci. USA, 96, 11041-11048 (1999).

19) Brown M. S., Ye J., Rawson R. B., Goldstein J. L., Cell, 100, 391-398 (2000).

20) Shimano H., Prog. Lipid Res., 40, 439-452 (2001).

21) Ishimoto K., Tachibana K., Hanano I., Yamasaki D., Nakamura H., Kawai M., Urano Y., Tanaka T., Hamakubo T., Sakai J., Kodama T., Doi T., Biochem. J., 429, 347-357 (2010) .

22) Mantovani R., Gene, 239, 15-27 (1999). 